DOI: $10.4067 / \mathrm{S} 0718-16202014000300008$

\title{
RESEARCH PAPER \\ Influence of long-chain fatty acids on weight gain of Hylastinus obscurus (Coleoptera: Curculionidae)
}

\author{
Dayand Toledo ${ }^{1,2}$, Leonardo Parra ${ }^{1}$, Ana Mutis ${ }^{1}$, Fernando Ortega ${ }^{3}$, Emilio \\ Hormazábal $^{1}$, and Andrés Quiroz ${ }^{1}$ \\ ${ }^{1}$ Departamento de Ciencias Químicas y Recursos Naturales, Universidad de La Frontera. Casilla 54-D, \\ Temuco, Chile. \\ ${ }^{2}$ Programa de Doctorado en Ciencias de Recursos Naturales, Universidad de La Frontera. Casilla 54-D, \\ Temuco, Chile. \\ ${ }^{3}$ Instituto de Investigaciones Agropecuarias, INIA Carillanca. Casilla 58-D, Vilcún, Chile.
}

\begin{abstract}
D. Toledo, L. Parra, A. Mutis, F. Ortega, E. Hormazábal, and A. Quiroz. 2014. Influence of long-chain fatty acids on weight gain of Hylastinus obscurus (Coleoptera: Curculionidae). Cien. Inv. Agr. 41(3): 357-364. The contents of long-chain fatty acids in non-polar root extracts from 1.6 year-old red clover plants of two cultivars (Superqueli INIA and Quiñequeli INIA) and one experimental line (Syn II Pre III), their relationships with H. obscurus populations, and the stimulant or deterrent effects of the root extracts and of individual fatty acids on the weight gain of $H$. obscurus were investigated. There was an inverse relationship between the insect population size and the palmitic acid content. The Superqueli INIA cultivar contained the highest palmitic acid content and the lowest insect load. When solutions of either palmitic or oleic acids were individually incorporated into an artificial diet, palmitic acid caused a decrease in weight gain, whereas the effect of oleic acid was similar to that of the phagostimulant saccharose. Hence, palmitic acid might be applied directly in H. obscurus control programs to prevent or reduce feeding and oviposition behaviors or might be used as a tool for selecting resistant cultivars.
\end{abstract}

Key words: Deterrent, Hylastinus obscurus, Trifolium pratense, palmitic acid.

\section{Introduction}

Red clover, Trifolium pratense L. (Fabaceae), is an economically important perennial legume pasture that is cultivated in numerous temperate regions worldwide both for its ability to produce large quantities of high-quality forage (Manosalva et al., 2011; Ghamkhar et al., 2012) and for its

Received March 14, 2014. November 3, 2014.

Corresponding author: andres.quiroz@ufrontera.cl adaptability to a wide range of soil types, $\mathrm{pH}$ levels and environmental management conditions (Steiner and Alderman, 2003). Although botanically considered a perennial plant, red clover does not persist for more than 4 years in a permanent pasture. Furthermore, several authors have reported that yields of T. pratense forage decline dramatically after two or three years of sowing because of the high mortality of plants, which is mainly attributed to fungal pathogens and insect infestations (Rhodes and 
Ortega, 1997; Steiner and Alderman, 2003). The red clover root borer, Hylastinus obscurus (Marsham; Coleoptera: Curculionidae), is a serious pest of red clover (Carrillo and Mundaca, 1974; Steiner and Alderman, 2003). This beetle feeds on roots, and it is considered to be the primary cause of declines in red clover (Quiroz et al., 2005). Pesticides have not been successful at controlling infestations of this root borer (Aguilera et al., 1996). Therefore, alternative strategies for controlling this insect are a high priority for red clover producers.

Since 1989, a red clover-breeding program has been conducted at the Centro Regional de Investigación Carillanca of the Instituto de Investigaciones Agropecuarias (INIA, Chile), with the main objectives of improving the survival, forage yield and persistence of plants compared to the Chilean diploid and the double-cut cultivar Quiñequeli INIA released in 1962 (Alarcón et al., 2010). Currently, we are investigating the role of plant chemistry in the life cycle of red clover root borer. The roles of volatile compounds released from red clover plants that elicit olfactory and behavioral responses from adult $H$. obscurus have been widely studied (Kamm and Buttery, 1984; Quiroz et al., 2005; Tapia et al., 2007; Palma et al., 2012; Parra et al., 2013), and the information generated to date has allowed for the development and incorporation of new management strategies into clover production programs (Ortega et al., 2014).

Manosalva et al. (2011) reported behavioral evidence that the long-chain free fatty acids, specifically, the lauric, palmitic and oleic acids, present in roots of 9-month-old red clover can, at close-range, act as semiochemicals between H. obscurus and red clover. In relation to this function, fatty acids such as linoleic acid and oleic acid have been reported to act as phagostimulants for root-feeding insects (Latchininsky et al., 2007), whereas Cantrell et al. (2011) demonstrated that linoleic acid, palmitic and oleic acids act as biting deterrents for the mosquito Aedes aegypti. In another study, Phelan et al.
(1991) determined that linoleic and oleic acids act as components of ovipositional cues for the navel orangeworm (Amyelois transitella). In contrast, palmitic, palmitoleic and oleic acids have been reported to act as oviposition deterrents for Lobesia botrana females (Gabel and Thiéry, 1996). Similarly, an elevated level of oleic acid has been suggested to act as an oviposition deterrent for the bruchid beetle ( $\mathrm{Cal}$ losobruchus maculatus). In addition, Hibbard et al. (1994) reported that linoleic and oleic acids act as attractants for larvae of the western corn rootworm (Diabrotica virgifera virgifera). Sarkar et al. (2013) noted that, of the 13 free fatty acids present in leaves of Momordica cochinchinensis, palmitic, stearic, oleic, linoleic, and alpha-linolenic acids attracted Epilachna dodecastigma in olfactometery bioassays, whereas only palmitic acid was attractive for Aulacophora foveicollis (Mukherjee et al., 2014). In summary, the reports regarding the roles of long-chain, free fatty acids in host location processes are few and contradictory. For example, the rose-ofSharon (Hibiscus syriacus) is an alternate host plant of the curculionid Anthonomus grandis. A study on the feeding behavior of $A$. grandis demonstrated that calyx tissue from buds of H. syriacus act as a feeding deterrent because of the presence of unsaturated fatty acids and their methyl esters. In contrast, saturated fatty acids and their methyl esters have generally been found to act as phagostimulants (Bird et al., 1987). Considering that the palmitic and oleic acids in red clover roots have been identified to attract $H$. obscurus in olfactometery and contact bioassays, the objectives of this study were 1) to analyze and compare, quantitatively by GC-FID, the contents of palmitic and oleic acids in root extracts of 1.6 year-old red clover plants of the Superqueli INIA and Quiñequeli INIA cultivars and the experimental line Syn II Pre III and 2) to evaluate the effects of these root extracts and their individual fatty acids as phagostimulants or feeding deterrents when separately incorporated into an artificial diet for H. obscurus. 


\section{Materials and methods}

\section{Plants}

Red clover plants of the Quiñequeli INIA and Superqueli INIA cultivars and the Syn II Pre III experimental line were collected from the Centro Regional de Investigación Carillanca at INIA (INIA-Carillanca; Vilcún, Región de La Araucanía, Chile). The plants were established in September 2011 under irrigated conditions. Entire plants were sampled in January 2013 with a sufficient amount of soil to avoid root damage.

\section{Insects}

Adults of $H$. obscurus were extracted from red clover plants cv. Redqueli INIA collected at INIA-Carillanca. The insects were removed from the roots and maintained in Petri dishes on pieces of red clover roots at $18-22{ }^{\circ} \mathrm{C}$ and $18 \mathrm{~L}: 6 \mathrm{D}$ light regimen. To perform the feeding bioassays, the insects were removed from the root pieces $10 \mathrm{~h}$ before each behavioral bioassay. H. obscurus individuals were used in the bioassays in the same month that they were collected, and each individual was used only once (Manosalva et al., 2011). In parallel, a monthly sampling (March-July) was performed to determine the population sizes of $H$. obscurus in the two cultivars and the experimental line of red clover. Each month, five plants of each cultivar and experimental line were randomly chosen for sampling. Both the aerial and belowground portions of plants were extracted intact and placed into a paper bag and transferred to the Chemical Ecology Laboratory of the Universidad de La Frontera. The belowground portion was separated from the aboveground portion, and roots were carefully cut open with a scalpel to evaluate the presence of adults and larvae of $H$. obscurus inside.

\section{Dichloromethane root extracts}

The root extracts were prepared according to the methodology reported by Tapia et al. (2007) and Manosalva et al. (2011), with minor modifications. Ten grams of dry root of each red clover cultivar and the experimental line (from $100 \mathrm{~g}$ of fresh root) were extracted with $2 \mathrm{~L}$ of dichloromethane $\left(\mathrm{CH}_{2} \mathrm{Cl}_{2}, 99 \%\right.$, GC-MS grade, Darmstadt, Germany) for $24 \mathrm{~h}$ at room temperature. After this period, the sample was filtered and the solvent was removed under reduced pressure on a rotary evaporator at $40{ }^{\circ} \mathrm{C}$ to produce a $\mathrm{CH}_{2} \mathrm{Cl}_{2}$ crude extract. An aliquot of $500 \mu \mathrm{L}$ of this extract was concentrated to 100 $\mu \mathrm{L}$ of solution under a flow of nitrogen. Then, the extract was transferred to a screw-cap amber bottle, labeled and stored at $4{ }^{\circ} \mathrm{C}$.

Preparation of fatty acid methyl esters for GC analysis

Before injection into the GC, the fatty acids were esterified. This esterification process reduces the absorption of the solute in the matrix and on the surface of the GC column, improving the separation of the compounds. Fatty acid methyl esters (FAMEs) were obtained by re-dissolving approximately $50 \mathrm{mg}$ of each dichloromethane root extract in $3 \mathrm{~mL}$ of an esterification reaction solution (methanol:hydrochloric acid:chloroform; $\left.\mathrm{MeOH}: \mathrm{HCl}: \mathrm{CHCl}_{3}, 10: 1: 1\right)$. The mixture was vortexed for $20 \mathrm{~s}$ at $120 \mathrm{rpm}$ before it was immediately incubated at $90{ }^{\circ} \mathrm{C}$ for 60 minutes to allow the esterification reaction to progress to completion. The reaction tubes were left at room temperature to cool. Subsequently, $1 \mathrm{~mL}$ of distilled water was added to each tube, and the mixture was agitated. Then, the FAMEs were extracted with a hexane/chloroform solution $(4: 1 \mathrm{v} / \mathrm{v}, 3 \times 2$ $\mathrm{mL}$ ). The samples were centrifuged at 3,000 rpm for $15 \mathrm{~min}$. The organic fractions were pooled, and hexane was added to a final volume of $10 \mathrm{~mL}$. 
Analysis and quantification of the fatty acid methyl esters using GC-FID

Fatty acids were identified as methyl esters using a gas chromatograph-flame ionization detector (GC-FID) (Fison GC 8000 series model, Italy) equipped with a BPX70 capillary column (30 m $\times 0.22 \mathrm{~mm} \times 0.25 \mu \mathrm{m}$ film thickness). A $1-\mu \mathrm{L}$ aliquot of sample was injected in the splitless mode at an injector temperature of $250{ }^{\circ} \mathrm{C}$. The initial column temperature was $100^{\circ} \mathrm{C}$ for $1 \mathrm{~min}$, increasing by $6{ }^{\circ} \mathrm{C} \mathrm{min}^{-1}$ to $250{ }^{\circ} \mathrm{C}$ before maintaining this temperature for $10 \mathrm{~min}$. A commercial fatty acid methyl ester mix (Sigma Aldrich) was used for identification by the comparison of retention times and for quantification by creating calibration curves.

\section{Analysis by GC-MS}

FAME identification was corroborated using a gas chromatograph (Model Focus; Thermo Electron, Waltham, MA) coupled to a mass spectrometer (model DSQ; Thermo Electron) (GC-MS) equipped with a DBP-5 capillary column $(30 \mathrm{~m} \times 0.22 \mathrm{~mm} \times 0.25 \mu \mathrm{m}$ film thickness). Helium was used as the carrier gas at a flow rate of $1.5 \mathrm{~mL} \mathrm{~min}{ }^{-1}$. Ionization was achieved by electron impact at $70 \mathrm{eV}$ and 250 ${ }^{\circ} \mathrm{C}$. The $\mathrm{GC}$ oven was programmed to remain at $40{ }^{\circ} \mathrm{C}$ for $1 \mathrm{~min}$ and then increase by $5{ }^{\circ} \mathrm{C}$ $\mathrm{min}^{-1}$ to $250^{\circ} \mathrm{C}$. The FAME identification was corroborated comparing the experimental mass spectra and those in the NIST mass spectral database (NIST ver. 2.0; Thermo).

\section{Feeding bioassays}

The feeding performance of $H$. obscurus adults was evaluated in a no-choice test using an artificial diet according to the methodology described by Faccoli and Schlyter (2007). Approximately 400 $\mu \mathrm{L}$ (density $\left.=1.05 \mathrm{~g} \mathrm{~mL}^{-1}\right)$ of a diet composed of $87.6 \%$ water, $2 \%$ cellulose, $2.6 \%$ glucose, $4.3 \%$ starch and $3.5 \%$ agar was added into a transparent glass tube $(6 \mathrm{~mm}$ diameter $\times 25 \mathrm{~mm}$ length). Then, $10 \mu \mathrm{L}$ of the $\mathrm{CH}_{2} \mathrm{Cl}_{2}$ crude extract of each cultivar and experimental line were added separately at two different concentrations (10 and $100 \mathrm{ppm}$ ) as proposed by Manosalva et al. (2011). To ensure a homogeneous distribution of the solution, the glass tubes were vortexed at $12 \mathrm{rpm}$ continuously for $15 \mathrm{sec}$. Thereafter, the tubes were incubated in the vertical position for $1 \mathrm{~h}$ at $21^{\circ} \mathrm{C}$ to allow the complete evaporation of the solvent. Subsequently, one previously weighed (iw) H. obscurus was introduced into each tube, which was then closed with a plastic cap. Each bioassay was replicated 20 times, and each adult insect was used only once. An artificial diet supplemented with $\mathrm{CH}_{2} \mathrm{Cl}_{2}$ was used as a control. An insect was allowed to feed for $5 \mathrm{~d}$ under darkness at room temperature. The insect was then weighed again (fw) at the end of the experiment. The feeding performance was evaluated by the weight increase (\%), where: weight increase $(\%)=(f w-i w) \times 100 / f w$. The same methodology was used to test both the oleic and palmitic acids from the dichloromethane root extracts at both 100 and 1,000 ppm. As controls, $H$. obscurus individuals were fed artificial diets supplemented with $\mathrm{CH}_{2} \mathrm{Cl}_{2}$ and the phagostimulant saccharose at the corresponding concentration.

\section{Data analyses}

The fatty acid contents and numbers of insects were analyzed by nonparametric Friedman tests followed by Conover- Inman tests $(\mathrm{P} \leq 0.05)$. The feeding bioassay results were analyzed by Kruskal-Wallis tests $(\mathrm{P} \leq 0.05)$, and statistical differences among groups were determined by Conover-Inman tests using the StatsDirect statistical software v.2.7.8 (StatsDirect Ltd., UK). 


\section{Results}

Chemical quantification of FAMEs and infestation by H. obscurus

There were significant differences $(\mathrm{P} \leq 0.05)$ among the cultivars and the experimental line in the concentrations of palmitic and oleic acids, ranging from $32 \mu \mathrm{g} \mathrm{g}^{-1}$ (dry weight root) in Syn II Pre III to $88 \mu \mathrm{g} \mathrm{g}^{-1}$ in Superqueli INIA for palmitic acid, and ranging from $6 \mu \mathrm{g}^{-1} \mathrm{~g}$ in Quiñequeli INIA to $12 \mu \mathrm{g} \mathrm{g}^{-1}$ in Superqueli INIA for oleic acid (Figure 1).

Concerning the population of $H$. obscurus, there were significant differences among the cultivars and the experimental line $(\mathrm{P} \leq 0.05)$ (Figure 1). The Syn II Pre III line contained a significantly greater mean number of root borers per root $(0.5$ $\pm 0.2)$ than Quiñequeli INIA $(0.3 \pm 0.1)(\mathrm{P}=0.03)$ and Superqueli INIA $(0.1 \pm 0.1)(\mathrm{P}=0.04)$. The difference between the Superqueli INIA and Quiñequeli INIA cultivars was also significant, with the latter cultivar infested by fewer $H$. obscurus individuals $(\mathrm{P} \leq 0.05)$.

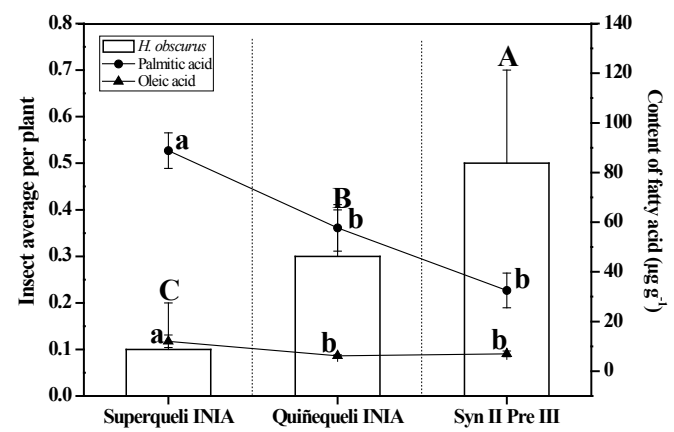

Figure 1. H. obscurus population sizes and fatty acid contents (per dry weight of root) of the Superqueli INIA and Quiñequeli INIA cultivars and the Syn II Pre III experimental line of red clover during the second growing season (January 2013). The fatty acid contents and the numbers of insects were each analyzed by a nonparametric Friedman test followed by a Conover-Inman test $(\mathrm{P} \leq 0.05)$. Different capital letters indicate significant differences in $H$. obscurus population sizes among the cultivars and experimental line. Lower case letters indicate significant differences in concentrations of fatty acids (palmitic acid and oleic acid) between each cultivar and the experimental line, but not between the two cultivars. The bars represent the standard errors.
Feeding bioassay

In general, the insect weights decreased significantly when dichloromethane root extracts $(10$ or $100 \mathrm{ppm}$ ) were added to the diet (Figure 2) $(\mathrm{P} \leq 0.05)$. The only increase in insect weight was observed when the diet was supplemented with the dichloromethane root extract from the Syn II Pre III experimental line at $100 \mathrm{ppm}(1.8 \%$; $\mathrm{P} \leq 0.05$ ) (Figure 2).

Figure 3 presents the weight gain of $H$. obscurus when fed a diet supplemented with palmitic acid or oleic acid. When the insect was exposed to a diet supplemented with 100 or 1,000 ppm palmitic acid, the weight losses of H. obscurus were greater than those of the control (both diets with and without saccharose) and oleic acid diets. In contrast, oleic acid stimulated a weight increase in H. obscurus at both evaluated concentrations, similar to the results for the phagostimulant saccharose $(\mathrm{P} \leq 0.05)$.

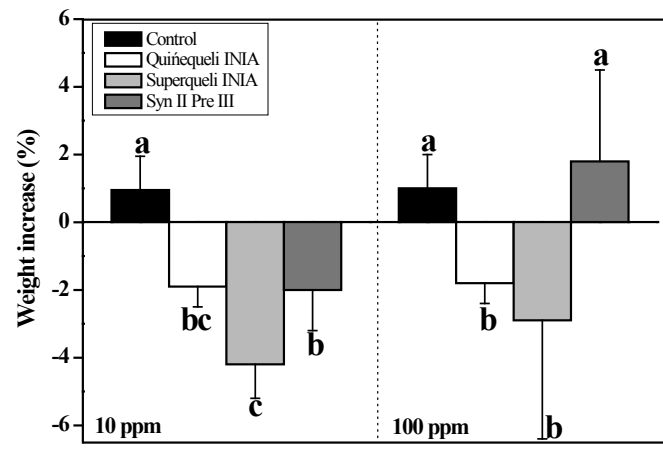

Concentration (ppm)

Figure 2. Weight increases $(\% \pm \mathrm{SE})$ of $H$. obscurus individuals fed an artificial diet supplemented with dichloromethane $\left(\mathrm{CH}_{2} \mathrm{Cl}_{2}\right)$ crude extracts of red clover roots of two different cultivars (Quiñequeli INIA and Superqueli INIA) and an experimental line (Syn II Pre III) at 10 and $100 \mathrm{ppm}(\mathrm{n}=20)$. Control $=$ artificial diet with $\mathrm{CH}_{2} \mathrm{Cl}_{2}$. Different letters indicate significant differences between treatments and controls based on a nonparametric Kruskal-Wallis test followed by a Conover-Inman test $(\mathrm{P} \leq 0.05)$. 


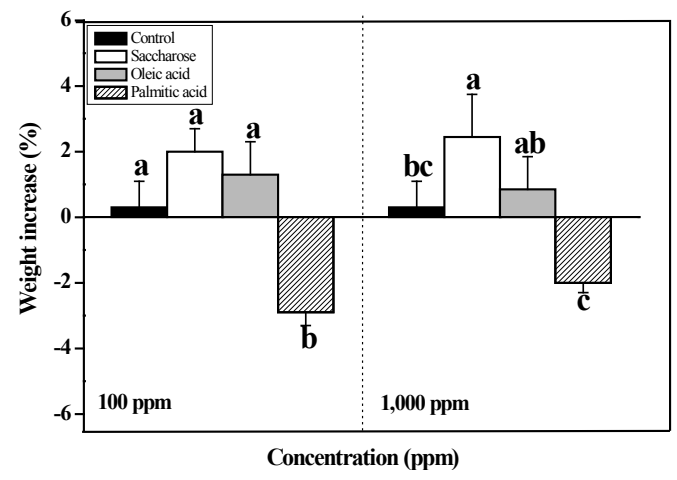

Figure 3. Weight increases $(\% \pm \mathrm{SE})$ of $H$. obscurus individuals fed an artificial diet supplemented with either oleic or palmitic acids at 100 or $1,000 \mathrm{ppm}(\mathrm{n}=15)$. Controls $=$ artificial diet supplemented with $\mathrm{CH}_{2} \mathrm{Cl}_{2}$ or saccharose (positive control). Different letters indicate significant differences between treatments and controls based on a nonparametric Kruskal-Wallis test followed by a ConoverInman test $(\mathrm{P} \leq 0.05)$. The bars represent the standard errors.

\section{Discussion}

During the processes of food location, competitor avoidance, and intraspecific communication, insects respond to several chemical signals emitted from their environment (Ruther et al., 2002). The process of host-plant selection by an insect is divided into several orientation-steps, including landing, probing, feeding and ovipositioning. After arriving at the food resource, an insect is likely to contact additional stimuli that can either stimulate a feeding behavior, keeping the insect at the resource, or inhibit that behavior, resulting in the rejection by the insect and, possibly, its departure from the resource (Foster and Harris, 1997). Stimulants and deterrents can be involved in either feeding or ovipositioning behaviors.

The number of insects that can infest the roots of red clover is a result of the number of oviposited eggs (Alarcón et al., 2010). Our results suggest that the studied red clover cultivars and the experimental line contain fatty acids in variable proportions with varying degrees of stimulant and deterrent activities. However, future research should focus on evaluating all of the other fatty acids present in the crude extract at multiple concentrations to rule out any potentially toxic effects that may have been masked by the antifeedant effect.

In this investigation, an inverse relationship between the H. obscurus population size and the palmitic acid content was observed. The lowest population size of this insect was found in the Superqueli INIA cultivar, which has been categorized as resistant to H. obscurus (Alarcón et al., 2010), and this cultivar also contained the highest content of palmitic acid. Furthermore, insects fed an artificial diet supplemented with the root extract from this cultivar exhibited a greater weight loss. The significantly greater insect weight loss of $H$. obscurus individuals fed a diet supplemented with palmitic acid suggests that this fatty acid could play a role as an antifeedant in the host recognition process of this curculionid (Figure 3). A similar antifeedant effect of palmitic acid on Leptinotarsa decemlineata has been reported by Santana et al. (2012); the effective antifeedant dose was approximately $50 \mu \mathrm{g} \mathrm{cm}^{-2}$ of palmitic acid present in Echium wildpretii. Although, there are few reports concerning the antifeedant effect of hexadecanoic acid, its role as an oviposition deterrent has been previously demonstrated. For example, a bioassay of the ovipositional site preferences of Lobesia botrana females conducted by Gabel and Thiéry (1996) demonstrated that treatments with palmitic, palmitoleic and oleic acids resulted in the greatest avoidance oviposition indices. Oleic acid has been reported to act as either a stimulant or a deterrent of oviposition depending on the concentration and solution mixture in which it occurs (Parr et al., 1998). In this study, the effects of the oleic acid treatments on feeding were similar to those of the phagostimulant saccharose (Figure 3). During host plant selection, females of this insect frequently eat and then oviposit; therefore, oleic acid might be a stimulant for infestation.

The results of this study indicate that palmitic acid should be considered a deterrent, while oleic acid acts as a phagostimulant, but further 
experiments on oviposition in these red clover cultivars and the roles of long-chain fatty acids in this process are required to gain a more in-depth understanding of the effects of these compounds on plant infestations.

\section{Acknowledgements}

Andrés Quiroz thanks the Project FONDECYT 1141245 (Fondo Nacional de Ciencia y TecnologíaChile), which provided funding for this research.

\title{
Resumen
}

\begin{abstract}
D. Toledo, L. Parra, A. Mutis, F. Ortega, E. Hormazábal y A. Quiroz. 2014. Influencia de ácidos grasos de cadena larga sobre el aumento de peso de Hylastinus obscurus (Coleoptera: Curculionidae). Cien. Inv. Agr. 41(3):357-364. El contenido de ácidos grasos de cadena larga en extractos apolares de raíces de trébol rosado de 1,6 años de edad provenientes de dos cultivares (Superqueli INIA y Quiñequeli INIA) y una línea experimental (Syn II Pre III), su relación con poblaciones de H. obscurus, y el efecto estimulante o disuasivo de extractos de raíces y ácidos grasos individuales sobre la conducta de alimentación de $H$. obscurus fueron investigados. Se determinó una relación inversa en el cultivar Superqueli INIA entre la población de insectos y el contenido de ácido palmítico. Cuando soluciones de ácido palmítico y oleíco fueron incorporadas individualmente en una dieta artificial, solo el ácido palmítico mostró un efecto disuasivo en la alimentación, mientras que el ácido oleico mostro un efecto similar al fagoestimulante sacarosa (control positivo). Por lo tanto, el ácido palmítico podría ser utilizado en programas de control de H. obscurus aplicado directamente para prevenir o reducir la conducta de alimentación y oviposición, o convertirse en una herramienta para la selección de cultivares resistentes a este insecto.
\end{abstract}

Palabras clave: Ácido palmítico, disuasivo, Hylastinus obscurus, Trifolium pratense.

\section{References}

Aguilera, A., E. Cisternas, M. Gerding, and H. Norambuena. 1996. Plagas de las praderas. In: Ruiz, I. (ed.). Praderas para Chile. Segunda edición. Instituto de Investigaciones Agropecuarias (INIA), Ministerio de Agricultura. Santiago, Chile. p. 309-339.

Alarcón, D., F. Ortega, F. Perich, F. Pardo, L. Parra, and A. Quiroz. 2010. Hylastinus obscurus (Marsham) and the yield of cultivars and experimental lines of red clover (Trifolium pratense L.). R.C. Suelo Nutr. Veg. 10:115-125.

Bird, T.G., P.A. Hedin, and Burks, M.L. 1987. Feeding deterrent compounds to the boll weevil, Anthonomus grandis Boheman in Rose of Sharon, Hibiscus syriacus L. J. Chem. Ecol. 13: 1087-1097.

Cantrell, Ch., A. Ali, S. Duke, and I. Khan. 2011. Identification of mosquito biting deterrent con- stituents from the Indian folk remedy plant Jatropha curcas. J. Med. Entomol. 48: 836-845.

Carrillo, R., and N. Mundaca. 1974. Biología de Hylastinus obscurus (Marsham) Col., Scolytidae. Agric. Téc. 34:28-35.

Faccoli, M., and F. Schlyter. 2007. Conifer phenolic resistance markers are bark beetle antifeedant semiochemicals. Agric. For. Entomol. 9:237 - 245.

Foster, S.P., and M.O. Harris. 1997. Behavioral manipulation methods for insect pest-management. Ann. Rev. Entomol. 42:123-146.

Gabel, B., and D. Thiéry. 1996. Oviposition response of Lobesia botrana females to long-chain free fatty acids and esters from its eggs. J. Chem. Ecol. 22:161-171.

Ghamkhar, K., S. Isobe, P. Nichols, T. Faithfull, M. Ryan, R. Snowball, S. Sato, and R. Appels. 2012. The first genetic maps for subterranean clover (Trifolium subterraneum L.) and comparative ge- 
nomics with $T$. pratense L. and Medicago truncatula Gaertn. to identify new molecular markers for breeding. Mol. Breeding 30:213-226.

Hibbard, B., E. Bernklau, and L. Bjostad. 1994. Long-chain free fatty acids: Semiochemicals for host location by western corn rootworm larvae. J. Chem. Ecol. 20:3335-3344.

Kamm, J.A., and R.G. Buttery. 1984. Root volatile components of red clover: Identification and bioassay with the clover root borer. Environ. Entomol. 13:1427-1430.

Latchininsky, A., S. Schell, and J. Lockwood. 2007. Laboratory bioassays of vegetable oils as kairomonal phagostimulants for Grasshoppers (Orthoptera: Acrididae). J. Chem. Ecol. 33:1856-1866.

Manosalva, L., F. Pardo, F. Perich, A. Mutis, L. Parra, F. Ortega, R. Isaacs, and A. Quiroz. 2011. Behavioral response of clover root borer to long-chain fatty acids from young red clover (Trifolium pratense) roots. Environ. Entomol. 40:399-404.

Mukherjee, A., N. Sarkar, and A. Barik. 2014. Longchain free fatty acids from Momordica cochinchinensis leaves as attractants to its insect pest, $\mathrm{Au}$ lacophora foveicollis Lucas (Coleoptera: Chrysomelidae). J. Asia Pac. Entomol. 17:229-234.

Ortega, F., L. Parra, and A. Quiroz. 2014. Breeding red clover for improved persistence in Chile: a review. Crop Pasture Sci. 65:1138-1146.

Palma, R., A. Mutis, L. Manosalva, R. Ceballos, and A. Quiroz. 2012. Behavioral and electrophysiological responses of Hylastinus obscurus to volatiles released from the roots of Trifolium pratense L. J. Soil Sci. Plant Nutr. 12: 183-193.

Parra, L., A. Mutis, F. Ortega, and A. Quiroz. 2013. Field response of Hylastinus obcurus Marsham (Coleoptera: Curculionidae) to E-2-hexenal and limonene, two host-derived semiochemicals. Cien. Inv. Agr. 40:637-642.
Phelan, P., C. Roelofs, R. Youngman, and T. Baker. 1991. Characterization of chemicals mediating ovipositional host-plant finding by Amyelois transitella Females. J. Chem. Ecol. 17:599-613.

Quiroz, A., F. Ortega, C. Ramirez, L. J. Wadhams, and K. Pinilla. 2005. Response of the beetle Hylastinus obscurus Marsham (Coleoptera: Scolytidae) to red clover (Trifolium pratense L.) volatiles in a laboratory olfactometer. Environ. Entomol. 34:690-695.

Rhodes, I., and F. Ortega. 1997. Plant breeding achievements and prospects, Forage legumes. In: Weddell, J.R. (ed.). Seeds of Progress. British Grassland Society. Symposium \#31. Nottingham, UK. p. 15-27.

Ruther, J., T. Meiners, and J. Steidle. 2002. Rich in phenomena-lacking in terms. A classification of kairomones. Chemoecology 12:161-167.

Santana, O., M. Reina, B. Fraga, J. Sanz, and A. González-Coloma. 2012. Antifeedant activity of fatty acid esters and phytosterols from Echium wildpretii. Chem. Biodivers. 9:567-576.

Sarkar, N., A. Mukherjee, and A. Barik. 2013. Olfactory responses of Epilachna dodecastigma (Coleoptera: Coccinellidae) to long-chain fatty acids from Momordica charantia leaves. Arthropod Plant Interact. 7:339-348.

Steiner, J., and S. Alderman. 2003. Red clover seed production. VI. Effect and economic of soil $\mathrm{pH}$ adjusted by lime application. Crop Sci. 43:624630.

Tapia, T., F. Perich, F. Pardo, G. Palma, and A. Quiroz. 2007. Identification of volatiles from differently aged red clover (Trifolium pratense) root extracts and behavioural responses of clover root borer (Hylastinus obscurus) (Marsham) (Coleoptera: Scolytidae) to them. Biochem. Syst. Ecol. 35:61-67. 